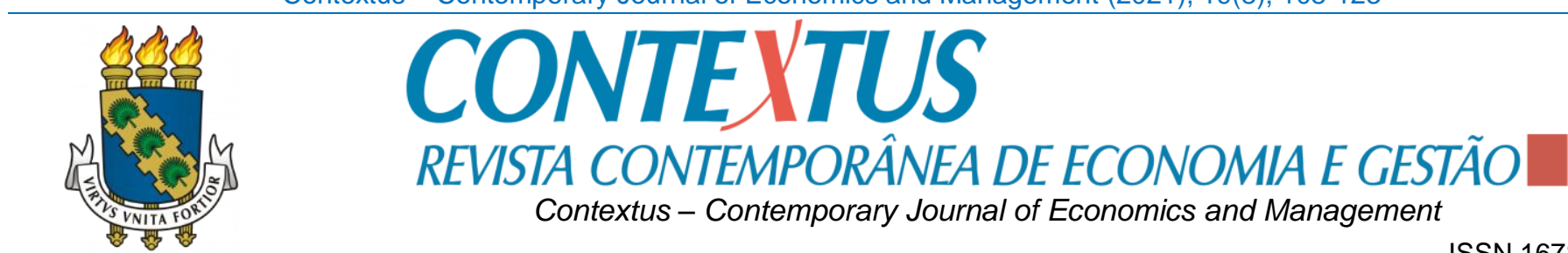

FEDERAL UNIVERSITY

ISSN 1678-2089

OF CEARÁ

www.periodicos.ufc.br/contextus

ISSNe 2178-9258

\title{
Antecedents of entrepreneurship in the career trajectories of junior enterprises alumni
}

\section{Antecedentes do empreendedorismo na trajetória de carreiras de egressos de empresas juniores \\ Antecedentes del emprendedorismo en la trayectoria profesional de los egresados de empresas junior}

\section{Aleciane da Silva Moreira Ferreira \\ https://orcid.org/0000-0001-5658-9684 (D) Professor at the Bahian Federal Institute $\mathrm{PhD}$ in Administration from the Federal University of Bahia \\ alecyane@yahoo.com.br \\ Elisabeth Loiola \\ https://orcid.org/0000-0003-3759-9048 (D) Professor at the Federal University of Bahia $\mathrm{PhD}$ in Administration from the Federal University of Bahia \\ beteloiola10@gmail.com}

\section{Sônia Maria Guedes Gondim}

https://orcid.org/0000-0003-3482-166X (i)

Professor at the Federal University of Bahia $\mathrm{PhD}$ in Psychology from the Federal University of Rio de Janeiro

sggondim@gmail.com

https://doi.org/10.19094/contextus.2021.62492 do

\begin{abstract}
The objective of this study was to advance the understanding of individual and contextual antecedents of entrepreneurship in the career trajectory of junior enterprises alumni. Semistructured interviews were done with a sample of 15 entrepreneurs. The collected contents were submitted to thematic content analysis of the individual narratives. The results show, among other aspects, that there are multiple motivations for starting a venture and that the experience in junior enterprises helps in the development of attitudes favorable to entrepreneurship. The perception of the interviewees was that university education offers few entrepreneurial training opportunities. In addition, a simplified comprehensive model based on the trajectories analyzed was formulated, which may help guide entrepreneurial educational actions in the university context.
\end{abstract}

Keywords: entrepreneurship; entrepreneurial intention; junior enterprises; entrepreneurial education; university context.

\section{RESUMO}

Objetiva-se avançar na compreensão dos antecedentes individuais e contextuais do empreendedorismo na trajetória de carreira de empreendedores egressos de empresas juniores. Entrevistas semiestruturadas foram feitas com 15 empreendedores. As narrativas individuais foram submetidas à análise de conteúdo temático categorial. Os resultados apontam haver motivações múltiplas para empreender e que a experiência em empresas juniores ajuda no desenvolvimento de atitudes favoráveis ao empreendedorismo. $\mathrm{Na}$ percepção dos entrevistados, o ensino universitário oferece poucas oportunidades de formação empreendedora. Com base nas trajetórias, foi proposto um modelo compreensivo simplificado, que poderá contribuir para orientar ações educacionais empreendedoras no contexto universitário.

Palavras-chave: empreendedorismo; intenção empreendedora; empresas juniores; educação empreendedora; contexto universitário.

\section{RESUMEN}

El objetivo es avanzar em La comprensión de los antecedentes individuales y contextuales Del emprendedorismo em La trayectoria profesional de los jóvenes egresados del empresas junior. Se realizaron entrevistas semiestructuradas con 15 empresarios. Las narraciones individuales se sometieron a um análisis de contenido temático categórico. Los resultados indican que existen múltiples motivaciones para el emprendedorismo y que la experiencia en empresas Junior ayuda a desarrollar actitudes amigables com el emprendedorismo. Según los encuestados, La educación universitária ofrece pocas oportunidades de formación empresarial. Sobre la base de las trayectorias, se propusoun modelo integral simplificado, que puede ayudar a guiar las acciones educativas emprendedoras em el contexto universitário.

Palabras clave: empreendedorismo; intencion empreendedora; empresas junior; educacion empreendedora; contexto universitario.

How to cite this article:

Ferreira, A. S. M., Loiola, E., \& Gondim, S. M. G. (2021). Antecedents of entrepreneurship in the career trajectories of junior enterprises alumni. Contextus - Contemporary Journal of Economics and Management, 19(8), 108-123. https://doi.org/10.19094/contextus.2021.62492 


\section{INTRODUCTION}

The definition of entrepreneurship is centered on the exploration of opportunities based on the creation of businesses / startups / innovations and on the entrepreneur's personality traits, which include the motivations and behaviors related to persistence, planning, independence, self-confidence, commitment, persuasion, proactivity, search for opportunities and so forth (Ferreira et al., 2020; Cooley, 1990). The behavioral study of entrepreneurs has been based on the theory of planned behavior (Ajzen, 1991), which presents some factors that can explain the intention of putting into practice a business idea. Such antecedent factors are attitudes (positive and/or negative assessments), subjective norms (social influences) and perceived behavioral control (perception of viability), which, together, influence entrepreneurial intention. The assumption is that there is a strong relation among intention, disposition and future behavior. Thus, entrepreneurial behavior corresponds to a type of planned behavior, considering that the creation of a new company requires time, planning oriented towards ends and means, and a high degree of cognitive processing for which models based on the theory of planned behavior have been proven robust in studies on entrepreneurship.

An audience that has been increasingly investigated in this context is university students (Linan \& Fayole, 2015), whose professional choices may involve an entrepreneurial career, such as opening a business, succession of parenting businesses, advising new businesses and so forth. Most studies that address university students' entrepreneurial intention use the perspective of future career choice (Linan \& Fayole, 2015), without advancing the understanding of individual and contextual factors in the trajectory of those students who put their intention into practice - for example, students egress from junior enterprises (JEs), who usually go through experiences related to entrepreneurship throughout the course, developing skills to open their own businesses (Campos, 2015). Initially located in France and later spread around the world, JEs are characterized by a type of entrepreneurial training in the university environment, which, by enabling the dialogue between theory (academic content) and practice, favors the development of entrepreneurial attitudes and behaviors in university students (Campos, 2015; Delaney et al., 2019; Ferreira \& Freitas, 2013; Ngan \& Khoi, 2020).In other words, it is a space in which the students manage a real business and acts as professional consultants in their area.JEs function as a field of practices seen as entrepreneurial, contribute to the construction of the relationship network, and also promote student contact with other entrepreneurs, who serve as reference models (Reeves et al., 2019; Savoie et al., 2018).

The experience in junior enterprises tends to be a very strong catalyst for entrepreneurial career intentions in that it: (i) reinforces social relationships, allowing familiarity with models to be followed (Cortez et al., 2019; Varamaki et al., 2015); (ii) favors the development of competencies in running a business, in consulting, and in network development (Delaney et al., 2019; Salusse \& Andreassi, 2016); (iii) stimulates reflection on the relationships between society, markets, and universities (Campos, 2015; Palassi et al., 2020); and (iv) is a space for experimentation and learning through mistakes and successes, and through relationships with other people (Zampier \& Takahashi, 2011).

Thus, entrepreneurs learn through practical experience (Savoie et al., 2018). The context of the experience in junior enterprises makes students learn to create and deal with opportunities and people, in addition to improving technical competencies (organization, planning, etc.), of a conceptual domain (Man, 2001; Tittel \& Terzidis, 2020). The support and promotion of junior enterprises is shown to be a positive policy for entrepreneurial career intentions.

Trajectories of entrepreneurs who are alumni from junior enterprises (JEs) reveal senses and meanings addressed by theories and concretized in entrepreneurial practices. Through their trajectories it is possible to make inferences about the motivations for starting a venture, the influence of family context, the quality of university experiences, including junior enterprises experience, the construction of relationship networks, and the development of entrepreneurial competencies.

However, the development of attitudes favorable to entrepreneurship does not ensure entrepreneurial action (Krueger \& Carsrud, 1993), indicating the influence of contextual variables and personal characteristics to actually make the intention come true in practice (Linan \& Fayolle, 2015).

Entrepreneurial narratives of junior enterprises alumni appears to be an effective and appropriate way to positively change individuals' perception of entrepreneurship Fellnhofer's (2020) across of individual and contextual variables. These narratives can facilitate the emergence of unique characteristics and experiences of the subjects and their connections with the contexts of practices, also applying to research on the dynamics of contemporary entrepreneurial careers (Komulainen et al., 2020).

The self-report of entrepreneurial careertrajectories can also make it possible to become aware of how the narrator interprets the events of his/her life, in addition to giving the interviewer access to these senses and meanings attributed retrospectively (Fina, 2015). This understanding allows inferences about motivations, attitudes, expectations, experiences, entrepreneurial identity and personal traits (individual antecedents), as well as the impacts of the actor's interactions with the social surroundings and influence groups (contextual antecedents) (Linan et al., 2018). 
Therefore, this study aims to answer the following question: how does the individual and contextual antecedents of entrepreneurship contribute to the career trajectory of junior enterprises alumni? Adopting Ajzen's Theory of Planned Behavior (TPB) (1991), widely used in studies of entrepreneurial intentions (Engle et al., 2010; Paiva et al., 2020), the qualitative study proceeded in formulating a simplified comprehensive theoretical model regarding the individual and contextual antecedents of the decision to start a venture, offering additional contributions in relation to the quantitative studies on antecedents of entrepreneurship (Kautonen et al., 2015), which may ultimately guide entrepreneurial educational actions in the university context. This study advances theoretically as it proposes in its formulated model three levels of explanatory factors of entrepreneurship (individual, social and institutional support) and suggests interrelations among the TPB variables (attitudes, subjective norms and perceived behavioral control) and new variables (entrepreneurial skills, entrepreneurial education, motivations and planning). The main practical contributions are directed to the educational environment, where those spaces that foster entrepreneurship (JEs) need to integrate teaching, extension and research, suggesting an opportunity for higher education to formalize entrepreneurial education based on an already established and coherent experience with their own guidelines. Receiving due attention and institutional support, the creation of multidisciplinary JEs can also enhance the students' experience (Campos, 2015), preparing them for the reality of the entrepreneurial context in which: a) the interprofessional work prevails, b) social skills inherent in collaborative work are increasingly valued, c) the exercise of perseverance attitude opens doors to creativity and d) the safe training environment leads to the flexibilization of thoughts and the relativization of losses and failures, in addition to promoting critical reflections on the social role of entrepreneurship for the community in which it operates.

The following two subsections present the main individual and contextual factors considered as predictors of entrepreneurship that guided the preparation of the interview script.

\section{THEORETICAL FRAMEWORK}

In this section, the individual and contextual factors explaining the entrepreneurship are presented. The main individual predictors of entrepreneurial intention are: attitudes, perceived control, risk propensity, motivations, planning and skills. The main contextual predictors are families, network of friends and entrepreneurial education, which operate as models to be followed and as support to business development (Linan \& Fayole, 2015; Ferreira et al., 2017). The explanation of those factors strengthens the understanding of their role in materialising students' entrepreneurial idea, as postulated by the TPB by Ajzen (1991), the main theory used to study behavioral intention.

\subsection{Individual factors explaining the entrepreneurship}

The study by Vale et al. (2014) concluded that the reasons for starting a venture go beyond the opportunitynecessity dualism, that is, the creation and/or discovery of opportunities (Shane \& Venkataraman, 2000) and also the fear of unemployment, especially in developing countries (GEM, 2020). This assertion is consistent with the view that entrepreneurial career intention is a multidimensional and multi- causal phenomenon, influenced by various factors of personal and contextual origin.

One of the most important predictors of entrepreneurial action is the need for achievement (BarbaSánchez \& Atienza-Sahuquillo, 2012; McClelland, 1965), that is, the search for autonomy, personal and professional development, and assumption of responsibilities. Another strong predictor is the attitude towards the entrepreneurial career, which makes the potential entrepreneur assess positively and engage in behaviors in this direction, or critically evaluate it, redirecting his/her career (Ajzen, 1991; Linan \& Fayolle, 2015).

In addition to the need for achievement and an attitude towards entrepreneurship, other variables at the individual level contribute to transforming intention into entrepreneurial action, such as the perception of control (internal locus of control) over the future success of the enterprise. And past experience has an important role in this process. The acquired knowledge, when mixing results of experiences with opportunities and also with obstacles and impediments, increases the young person's capacity to deal with issues that involve risk control and their positive or negative career assessment (Ajzen, 1991, Savoie et al., 2018).

The propensity to take calculated risk is also a motivating factor for the creation of one's own business, but the legal obligations and need to become clear (Malach \& Malach, 2019; Parreira et al., 2011). But there are differences between entrepreneurs. Entrepreneurs less inclined to calculated risk tend to put their ideas into practice even in the face of uncertain scenarios. Those more inclined to calculated risk, in turn, tend to be more reticent in their decisions. The studies by Chandler et al. (2011) clearly showed that university students are cautious in investing resources, contrary to the general pattern of Brazilian entrepreneurs (GEM, 2015). There are, however, planning tools and instruments and approaches that assist decision making in environments marked by different degrees of uncertainty, which expands the possibilities for teaching entrepreneurial competencies.

Traditional and current planning approaches are not limited to the construction of mere business plans, as commonly taught in entrepreneurship courses. Investing in business plans certainly helps entrepreneurs to predict risks, facilitates systematic analyses based on multiple variables, and broadens the understanding of the relationship between intention, action, and entrepreneurial performance (Botha \& Robertson, 2014). The value attributed to the business plan depends, however, on the 
context. Where there are high levels of uncertainty and volatility in start-up environments, there is a need for constant redefinition of actions and strategies to keep up with socioeconomic changes, which requires the mastery of planning techniques and tools appropriate for such environments. On the other hand, in more stable environments, more traditional technical approaches and planning tools can produce enough information to guide the action of entrepreneurs. Thus, entrepreneurial activity requires both prior planning (planning as a cause causation) and planning adjusted to the circumstances (planning as an effect or consequence - effectuation) (Faia et al., 2014; Sarasvathy, 2001; Smith \& Pierre-André, 2020), which can be used together or separately. The planning as a consequence approach seems little explored, if not absent, in the undergraduate and graduate curricula in Brazil, although it is in the basis of Sarasvathy's (2001) definition of entrepreneurship, one of the most respected and used definitions in the world's major entrepreneurship research centers.

Some studies additionally suggest that entrepreneurial competencies may differ between the sexes (Shinnar et al., 2012; Sánchez-Escobedo et al., 2016), reflecting the socialization context of men and women in which the social stereotype is cultivated of the entrepreneurial man as the one more inclined to risk (Gupta et al., 2008; Sweida \& Reichard, 2013). Women develop, for example, more relational and organizational competencies (Mitchelmore \&Rowlew, 2013), being less inclined to take risks (Dawson \& Henley, 2015). They also make more use of close ties to obtain information and social support (Vale et al., 2011). Men tend to be more objective and technical (Souza, 2005). It was seen earlier that the trajectories of student entrepreneurs are more influenced by social networks, by the models to follow, and by the support of family and friends. It was also observed that entrepreneurs vary among themselves according to their risk propensity. Here it is observed that women develop more relational competencies (networks) and use more close ties. Thus, the male superiority in the field of entrepreneurship suggested by the social stereotype of the entrepreneurial man does not seem to be sustained.

\subsection{Contextual factors explaining the entrepreneurship}

According to the TPB, subjective norms refer to the social pressure exerted on the individual regarding the behavior in question, that is, they are considered external influences on the behavior intention, such as social expectations, empathy and/or moral obligation. The valorization of entrepreneurship by the university student's social groups of reference (family, friends, university colleagues, etc.) works as a social norm to be followed, leading him/her to adopt entrepreneurial behaviors (Ajzen, 2011). The family's influence and social and/or material support (Engle et al., 2010; Gupta et al., 2008; Linan et al., 2011), as well as the entrepreneurial education environment (Lima et al., 2015; Linan et al., 2018; Moraes et al., 2018; Mushtaq et al., 2011; Salusse \& Andreassi, 2016) are already documented in the literature.

When the student's family has experience with entrepreneurship, their career intention is greater, even if they do not find financial support, as the socio-emotional support of the parents has a significant impact on their decisions (Sesen, 2013). The transformation of intention into action can be through the student's own business or through succession, which will determine the survival of the business and can also be understood as a moral obligation. A recent study by Giménez and Novo (2020) showed that external people are not a priority in the succession process, unless an incremental improvement in relation to family members is expected.

As for support from friends, the study by D'hont et al. (2016), who conducted an in-depth interview with ten young entrepreneurs from France, showed that friendship and affective ties contribute to the emergence and development of business, meeting what the TPB postulates about subjective norms. This support includes reinforcement of self-esteem, encouragement in decision making, expansion of relationship networks, indication of jobs and so forth (Kacperczyk, 2013).

On the university environment, the influence varies from country to country, as entrepreneurial education has different effects depending on the country's cultural values, the way entrepreneurial education is put into practice, the level of development of the country and its institutions to support entrepreneurship. Studies carried out in Norway, for example, suggest that entrepreneurial education does not predict students' entrepreneurial intention, as its labour market appears to be better structured, offering regular earnings considered excellent (Storen, 2014). In Brazil, however, although students demand a university environment more conducive to entrepreneurship, entrepreneurial education in the way it is being offered points out difficulties in fulfilling its role (Lima et al., 2015; Ferreira et al., 2017). Entrepreneurial intention at the time of college graduation does not seem to be sufficient for the new graduate to start a business, especially if he or she did not go through any relevant experience during the undergraduate period, such as experience in junior companies, participation in workshops, business games, business incubators, management skills development etc. In the same direction, other studies indicate that the student's relationship network has fulfilled the role of stimulating and supporting the opening of a business, more than the courses offered (Kacperczyk, 2013; Lima et al., 2015). Additionally, a recent study shows the willingness of young people to form new businesses after entrepreneurial education actions (Barbosa et al., 2020) in addition to business plan training, for example.

It is worth mentioning that the support of educational institutions is important to consolidate the entrepreneurial environment. Entrepreneurial education is positively related 
to the creation of opportunities and self-realization (Campos, 2015); this suggests that entrepreneurship education goes hand in hand with training aimed at developing the skills required to get a job.

\section{METHODOLOGY}

This is a qualitative study, which used semistructured interviews with graduates of junior companies who opened their own businesses or succeeded their parents. The afore mentioned interviews followed a previously defined script based on the specialized literature and elaborated as recommended by Wengraf (2001). Data analyze by means of prior thematic categorization (Bardin, 2009; Gondim \& Bendassolli, 2014), whose categories were developed based on theories and empirical evidence regarding the individual and contextual antecedents of the entrepreneur al career, that contributed to the formulation of a simplified comprehensive model based on the Theory of Planned Behavior (Ajzen, 1991).

\subsection{Participants}

Fifteen Junior Enterprise alumni who own the companies in which they work participated in the study. Nine were male; the average age was 28 years and the average time since opening the company was two years, although in one case the company has been operating for 12 years. Their university degrees were: business administration $(n=8)$, psychology $(n=1)$, social communication $(n=1)$, agronomic engineering $(n=1)$, public health engineering $(n=2)$, environmental engineering $(n=1)$, and civil engineering $(n=1)$. Table 1 presents the characteristics of the participants, which were separated by cases.

\section{Table 1}

Characteristics of the participants

\begin{tabular}{|c|c|c|c|}
\hline Cases & Age & Degree & Business \\
\hline Case 1 & 42 & Business administrator & Consulting \\
\hline Case 2 & 28 & Business administrator & Meat Shop \\
\hline Case 3 & 26 & Business administrator & Aesthetics \\
\hline Case 4 & 27 & Psychologist & Consulting \\
\hline Case 5 & 33 & Business administrator & Consulting \\
\hline Case 6 & 34 & Communicologist & $\begin{array}{l}\text { Fitness } \\
\text { Products }\end{array}$ \\
\hline Case 7 & 27 & Business administrator & Consulting \\
\hline Case 8 & 23 & Business administrator & Auto parts \\
\hline Case 9 & 23 & Civil engineer & Events \\
\hline Case 10 & 25 & Agronomic engineer & Parking \\
\hline Case 11 & 25 & Public health engineer & Consulting \\
\hline Case 12 & 26 & Public health engineer & Consulting \\
\hline Case 13 & 23 & Business administrator & Events \\
\hline Case 14 & 27 & $\begin{array}{l}\text { Environmental } \\
\text { engineer }\end{array}$ & Consulting \\
\hline Case 15 & 27 & Business administrator & $\begin{array}{l}\text { Wedding } \\
\text { products }\end{array}$ \\
\hline
\end{tabular}

Souce: Developed by the authors.

\subsection{Data collection instrument}

An interview script organized into themes was used to address aspects of the participants' trajectory that could answer the proposed questions, as described in Table 2.

\section{Table 2}

Topics covered in the interview

\begin{tabular}{|c|c|}
\hline \multirow{2}{*}{ Topics } & Objectives \\
\hline & Individual level \\
\hline Motivations & $\begin{array}{l}\text { Explore the type of motivation to } \\
\text { create the business. }\end{array}$ \\
\hline Attitude & $\begin{array}{l}\text { Explore entrepreneurial career } \\
\text { assessment. }\end{array}$ \\
\hline Perceived control & $\begin{array}{l}\text { Explore perceived risks related to the } \\
\text { business. }\end{array}$ \\
\hline Planning & $\begin{array}{l}\text { Explore how much investment there } \\
\text { was in business planning }\end{array}$ \\
\hline \multirow[t]{2}{*}{$\begin{array}{l}\text { Entrepreneurial } \\
\text { competencies and } \\
\text { sex }\end{array}$} & $\begin{array}{l}\text { Explore self-assessment of } \\
\text { entrepreneurial competencies and } \\
\text { sex difference. }\end{array}$ \\
\hline & Contextual level \\
\hline $\begin{array}{l}\text { Entrepreneurial } \\
\text { education }\end{array}$ & $\begin{array}{l}\text { Explore the role of the university in } \\
\text { the process opening a business }\end{array}$ \\
\hline Subjective norm & $\begin{array}{l}\text { Explore the support and } \\
\text { encouragement of family, friends and } \\
\text { university colleagues in creating the } \\
\text { business. }\end{array}$ \\
\hline
\end{tabular}

Source: Developed by the authors.

\subsection{Data collection procedure}

About ten junior enterprises and two student associations in the region of Salvador (BA) and its surrounding area received an invitation by e-mail and telephone to indicate alumni who had opened their own businesses. The referred organizations indicated about 20 entrepreneurs, whose sample selection was by convenience (Creswell, 2007). Former graduates from JEs who did not undertake businesses were not invited to participate, because the goal of this research was to analyze the influence of individual and contextual factors on the creation of businesses. The size of the participants' businesses was small, ranging from micro-enterprises to individual micro-entrepreneurs.In respect to ethical principles, accession to the research was voluntary, and these organizations merely supported the initiative. The 15 entrepreneurs who agreed to participate in the research were sent a free and informed consent form, in addition to ensuring their anonymity. The interviews, with an average duration of 50 minutes each, were carried out in person at their respective companies and through videoconferencing, having been recorded. The field research took place in late 2016 and early 2017.

\subsection{Data analysis procedure}

The interviews were transcribed (Hammersley, 2010) and coded by means of prior thematic categorization (Bardin, 2009; Gondim \& Bendassolli, 2014). Such categories were developed based on theories and empirical evidence regarding the individual and contextual antecedents of the entrepreneur al career. Prior categorization is the phase for organizing and classifying the corpus into a set of significant recording units; being a way to order, based on criteria, all the coded material (Gondim \& Bendassoli, 2014). Table 3 presents the category system. 
Thematic categories of the corpus

Individual Level

Motives of achievement (MA) - reasons related to achievement, improvement, seeking autonomy, persona and professional development, and assuming responsibilities (McClelland, 1965).

Motives of necessity (MN) - reasons related to the lack of alternatives and urgency in meeting personal and economic needs (GEM, 2015).

Motives of opportunity (MO) - a new business is started, even when there are employment alternatives. There is identification / discovery / creation and exploration of new market niches (GEM, 2015; Shane \& Venkataraman, 2000).

\begin{tabular}{ll}
\hline Attitude & $\begin{array}{l}\text { Attractiveness (AT) - positive affective assessment in relation to the act of starting a venture (Ajzen, 1991). } \\
\text { Critical sense (CS) - negative affective assessment of some aspects of entrepreneurship (Ajzen, 1991). }\end{array}$ \\
\hline $\begin{array}{l}\text { Perception of } \\
\text { control }\end{array}$ & $\begin{array}{l}\text { Greater propensity for calculated risk (PR) - the individual seeks to better assess potential risks (Baron \& } \\
\text { Ensley, 2006), having more need to feel control over the environment. } \\
\text { Less propensity for calculated risk (CR) - the individual takes more risks in business, without fear (GEM, } \\
\text { 2015), that is, accepts having less control over the environment. }\end{array}$ \\
\hline Planning & $\begin{array}{l}\text { Circumstantial planning (CP) - absence of formally prepared business planning, correcting steps during the } \\
\text { process (Sarasvathy, 2001). Planning as a consequence or effect of the course of entrepreneurial actions. }\end{array}$ \\
& $\begin{array}{l}\text { Formal planning (FP) - preparation of a more detailed business plan that guides entrepreneurial actions } \\
\text { (Sarasvathy, 2001). Planning as a cause, the first step to envision the success of the business. }\end{array}$ \\
\hline $\begin{array}{l}\text { Entrepreneurial } \\
\text { competencies }\end{array}$ & $\begin{array}{l}\text { Competency for Opportunity (OP) - ability to identify market trends and novelties (Man, 2001; Shane \& } \\
\text { Venkataraman, 2000). }\end{array}$ \\
\hline $\begin{array}{l}\text { Competency for Organization (OR) - capacity for leadership, planning, delegation, and control (Man, 2001). } \\
\text { Competency for Relationships (RL) - ability to manage conflicts and to communicate (Man, 2001). }\end{array}$ \\
$\begin{array}{l}\text { Fntrepreneurial } \\
\text { competencies } \\
\text { and sex }\end{array}$ & $\begin{array}{l}\text { Female Sex (AA) - female entrepreneurial actions are characterized by their capacity for analysis and attention } \\
\text { to detail (Mitchelmore \& Rowlew,2013). } \\
\text { Male Sex (AB) - male entrepreneurial actions are characterized by their capacity for objectivity, practicality, and } \\
\text { greater preparedness to deal with daily problems in business (Souza, 2005) }\end{array}$ \\
\hline
\end{tabular}

Contextual Level

Entrepreneurial

Practical Experience (PE) - exercise of business activities during the training process, oriented towards Education entrepreneurial activity (Brasil Junior, 2014).

Relationship Network (RN) - building social network strategies in developing entrepreneurial actions and market survival (Kacperczyk, 2013).

Financial and material support (FS) - financial and service support to establish the business (Mushtaq et al., 2011).

Subjective norm

Social support (SS) - support from networks of friends and family with entrepreneurial experience (Linan, Urbano \& Guerrero, 2011)

Source: Developed by author based on Ajzen (1991), Brasil Junior (2014), Kacperczyk (2013), Linan, Urbano and Guerrero (2011), Man (2001), Mitchelmore and Rowlew (2013), Mushtaq et al. (2011), Baron and Ensley (2006), and Souza (2005).

The transcripts of each of the 15 cases were read more than once seeking to encode words and phrases that would allow them to be allotted in the prior thematic categorization. The prior categories system, as shown in Table 3, proved to be adequate for coding the responses, although in some themes subcategories came up, which will be commented on in the results section.

\section{ANALYSIS AND DISCUSSION OF RESULTS}

The results are organized in three parts. In the first, the results are analyzed from a theoretical review standpoint. Then, the cases are reported in summary, seeking to characterize central aspects of the participants' trajectories. The contents of the first and second parts guide the development of the model presented in the third part, which relates the mutual influence of the antecedents of entrepreneurship in the career of the junior enterprise alumni.

\subsection{Discussion of reports on the interview \\ 4.1.1 Motivation}

All three previously categorized motivations were manifested in the trajectories of these young people. Motives of personal/professional achievement (MA) were manifested in eight cases, as observed in the case 15 entrepreneur's speech: "it was finding meaning at work. I started to feel a strong desire to express myself creatively, to put my talents at the service of the world". Motives of necessity (MN) were manifested in four cases, for instance case 14: "the company was born from this, from the difficulty of finding work; companies ask for experience". Motives of opportunity (MO) were manifested in four cases, for example case 5: "I discovered a market opportunity blended with my lifestyle".

There were 4 recorded cases with motivation to replace a family member (cases $2,7,8$, and 10). Case 8 , for example, says that he had to "take over the family business due to his father's death". Such motivation can be classified as "of necessity", which is the one that expresses a lack of alternatives and urgency in meeting personal and economic needs (GEM, 2020). In fact, the respondents did not have alternatives and were obligated to take charge to ensure the survival of the family business, as well as their own survival and that of those who depended on the business. Alternatively, the aforementioned cases can be classified as motivation by "family succession". In the entrepreneurship literature reviewed, motivation by family succession does not appear, although it is an extensively researched theme in the field of study on family businesses. Such a gap was also identified by Vale et al. (2014) and Giménez and Novo (2020). As previously mentioned, the family is a strong 
reference model for entrepreneurs, which would justify the creation of a new category of motivation, called "family succession".

In some cases, reasons were expressed simultaneously, as happened in case 1: "the reasons were market opportunity and coincident factors. In fact, opportunity and necessity are allied, along with wanting to have greater freedom to be able to manage one's own path and to be able to work in one's area of training". In this case 1 , we observe the presence of motives of opportunity, of necessity, and of achievement. Another illustration of multiple motivations is that of case 12, which combined market opportunity $(\mathrm{MO})$ with the desire to own one's own business (MA).

The analysis of the reasons for starting a venture in these 15 cases allows us to infer that, although there were cases of multiple motivations, the motives of opportunity, necessity, and to a greater extent, personal achievement are the ones most frequently stated by the interviewees. However, one cannot neglect the occurrence of cases with combinations of multiple motivations and even of categories of motivation not found in the reviewed literature. These latter occurrences seem to indicate that the motivations for entrepreneurship are more diversified than those that are located in the achievement $x$ necessity $x$ opportunity trinomial, questioning the widespread view on the part of the specialized literature that the motives of necessity, opportunity, and achievement are exclusive and exhaust the possible types of motivation.

Furthermore, although the results indicate that selfrealization is one of the prominent motivations in the cases studied, which is in line with McClelland's (1965) propositions, recents studies indicate that there is no ideal profile of traits and motivational factors that lead individuals to start a venture (Parreira et al., 2011). However, the personality traits approach continues to predominate in Brazilian academic circles.

Additionally, the results of this study show a profile different from most Brazilian entrepreneurs described in the GEM (2015), which points out that in developing countries, ventures are started more out of necessity. It is believed that because of their entrepreneurial learning in junior enterprises, the subjects of this study are able to develop competencies that expand their employment opportunities and, at the same time, make them visualize the entrepreneurial career as another alternative for putting into practice what they learned at the university (Delaney et al., 2019; Savoie et al., 2018; Zampier \& Takahashi, 2011). Corroborating this point of view, we cite case 2 ("The role of the university was to provide internships and participation in the JE in the last year") and case 3 ("The university brought out their aspect as leaders, identified since their time in school'). Future studies could go on to deepen these results, comparing the motivations of post-juniors and entrepreneurs who did not go through this experience, and even investigating in more detail the role of universities in the training of these latter entrepreneurs and the course offerings related to entrepreneurial training in the teaching units where they received their training.

\subsubsection{Attitude}

The categories attractiveness (AT) - positive affective assessment in relation to the act of starting a venture (Ajzen, 1991) - and critical sense (CS) - negative affective assessment of some aspects of entrepreneurship (Ajzen, 1991) - appeared in all cases, for example: "it is a challenging career, but if you meet the challenge, everything thrives" (case 10); "I don't think it's for everyone, you have to have a lot of guts, you have to have a lot of patience to see your friends in public service earning much more than you, but you can't put a price on having a new event, a new challenge every day, feeling like you're living, you know, you don't wait a year to see a good thing happen" (case 13).

From an attitudinal perspective, the positive affective assessment (AT) for the entrepreneurial career was clear in the following statements from the interviewees: "best decision to be made" (case 1), "more freedom" (case 11), "quality of life, professional achievement" (case 5), "emotional and psychological independence, creativity" (case 6), "control your hours" (case 3), and "exciting career" (case 15). It is observed that these statements express or are linked to personal factors. The negative affective assessment (CS), in turn, considers more factors of the environment and the entrepreneurial occupation, such as: "complexity of the tax burden and bureaucracy" (cases 1, 2, 5) "high responsibility" (case 6), "economic instability" (case 4), "a lot of pressure" (case 9), and "financial insecurity" (case 7).

In line with the studies by Ngan and Khoi (2020) and Linan and Fayolle (2015), who state that attitude is a strong predictor of the intention to start a venture, the trajectories of the cases studied suggest that both positive attitudes and critical attitudes relate to entrepreneurial action. In other words, the entrepreneurial action of the post-juniors is not preceded only by positive affective assessment. Critical aspects such as obstacles and challenges help in the decision making and shape actions in entrepreneurial practice, offering evidence from Ajzen's theory of planned behavior (1991), contrasting, however, with the widespread view that negative affective assessments always lead the subjects to redirect their efforts in terms of career choice. In the case of the entrepreneurs interviewed, the most critical assessments refer to characteristics of the business environment in Brazil and the lack of government support for entrepreneurship (e.g., high tax burden, lack of economic incentives, etc.).

Despite this critical assessment, none of the entrepreneurs revealed a desire to leave the area or the business. It is conjectured that decisions are guided by the balance between positive and negative affective assessments, considering that there is no situation in which only positive or negative affects prevail (Ajzen, 1991; Linan \& Fayolle, 2015).

The simultaneous presence of AT and CS challenges the naive but widespread vision of happy, delighted, noble, adventurous, super creative entrepreneurs, unrestricted risk takers, endowed with full rationality, which contributes to the idealization of profiles and traits to be pursued and 
emphasized in training courses. CS is fundamental for marking out, for example, actions to identify and explore opportunities in the market. It is also critical in signaling the need to strengthen competencies, whether through training or partnerships.

\subsubsection{Subjective norms}

The social support (SS) category was manifested in 12 cases. Family and friends, singly or together, were the most cited forms of social support, as illustrated by cases 1 ("Received socio- emotional support from parents"), 2 ("Received support from mother and sister"), 8 ("Received encouragement from family and friends"), 9 ("The support of his father, who is an entrepreneur, was fundamental [...] The network of friends provided by JE was essential"), 10 ("Received support from his uncle"), 13 ("The family supported him 100\% financially and emotionally, as well as the network of friends he created in JE, where he met his two partners"), and 14 ("She heard many 'noes', but colleagues helped her to publicize the business"). There are records, however, of indifference or lack of support from parents - "The family does not understand her option to earn money by doing what she loves. It is with the network of friends that she talks, whose friendship she made in JE" (case 15) and "The network of friends was important in helping her deal with diversity, but her family was indifferent" (case 3), as well as of a lack of encouragement from colleagues: "That's nothing, you will do a public job competition, this business of starting a company doesn't make you any money"; "Nobody believed it. I invited them to come to my office and when they got there, seeing the table, the computer, the books, asked: 'and where is the company' hahaha". There was also an interviewee who highlighted the experience she had with JE and with her father's company, who is an entrepreneur, as the main sources of support received (case 11).

The financial and material support (FS) category was manifested in five cases in relation to financial help from the family and material help from friends (e.g., brand building), such as in cases 12 and 14: "I received financial help and encouragement from my family"; "My university colleagues made the logo, the website".

There is a strong influence of the family with an entrepreneurial tradition on the career of subsequent generations. More than half of the entrepreneurs participating in this study have an entrepreneurial family, which suggests that the experience in the junior enterprise legitimizes and reinforces the attitudinal disposition awakened through these models who are close, as stated by the entrepreneur in case 14: "without a doubt the mirror at home makes a difference". This converges with the studies by Gupta et al. (2008), who explore this influence and reinforce the role of the entrepreneurial social norm, especially among families and friends who started their own businesses and were successful. On the other hand, normative beliefs on the part of university colleagues were not significant, corroborating the results of Engle et al. (2010) and Linan, Urbano and Guerrero (2011), in which in less developed regions, social support comes from closer relations, such as family and friends.

\subsubsection{Entrepreneurial education}

The practical experience (PE) and relationship network $(\mathrm{RN})$ categories were manifested simultaneously in eight cases, that is, participation in the junior enterprise enabled the construction of relationships, as cases 12 and 15 show: "It is with this network that I converse, brainstorm, look for ideas and inputs to help me lay out the business"; "It was in JE that I met my two partners, it was my main source of learning during college, where I was able to experience in practice what it was like managing a company and become familiar with the technical issues for structuring the business. The incentive and empowerment to start a venture came much more from JE". The practical experience (PE) category was manifested separately in seven cases, but the social relationship network (RN) was always accompanied by PE. There was no other evidence of the role of the university/school in stimulating entrepreneurship (Kacperczyk, 2013; Lima et al., 2015). The contact with related courses was not beneficial, as can be seen in case 15: "I had a course related to entrepreneurship and it was awful, it didn't help me at all, pardon my sincerity, but it really was very bad, it was like this, the basic of the basic, in short, it was terrible". The importance of the faculty's preparation proved to be fundamental, as the entrepreneur in case 3 states: "the professor at that moment is a game changer in the discipline, because he passes on the idea according to his own conception; while he has a relationship with entrepreneurship, the teaching and the content are different from those who do not have this contact".

These results are echoed in the studie by Salusse and Andreassi (2016), who criticize the teaching in entrepreneurship at universities for its lack of emphasis on experiential and dynamic methodologies that challenge students through the use of simulations, experimental laboratories, practices, and tests, stimulating critical thinking, and promoting maturation for the entrepreneurial career choice (Varamaki et al., 2015). In addition, these results are according with the study by Zawadzki et al. (2020), who deconstruct the neoliberal form of the entrepreneurial self in the university classroom and put a great deal of effort into giving the students the opportunity to experience firsthand the reality of organizational processes and problems.

\subsubsection{Planning}

The circumstantial planning (CP) category was manifested in 11 cases, as in cases 2 and 3: "The phase to get to here was not well planned, it was a succession of accidents, oddly enough, I did not do a business plan for this business"; "I didn't do planning itself before I started the business, but I was gradually changing, and at the time, when I had no experience, it got even more complicated. At that time I didn't record anything on paper. The business was already going, I had no discipline to stop and do it." 
Formal planning (FP) was mentioned by four interviewees, as can be seen in cases 5 and 7: "I spent 4 years maturing the idea"; "Everything we did was based on a business plan $(B P)$ even before the process was starting. We spent from 6 months to 1 year doing the BP, all the stages".

The formal part of the plans was more associated with the finances, even the entrepreneurs understanding its importance and knowing the business plan. Case 13 illustrates this finding: "we wanted to start and if we had spent a lot of time planning it would have been worse". This statement corroborates the approach of planning as a consequence or effect (effectuation) (Saravasthy, 2001; Smith \& Pierre-André, 2020), in which the market is the guide for the entrepreneur and is not stable in Brazil, making it difficult to systematize long-term plans. In other words, the dynamic context in which the entrepreneur operates requires changes and adjustments to planning in light of the challenges and problems encountered (Faia et al., 2013; Smith \& Pierre-André, 2020).

Another aspect to consider is that the disciplines of planning and doing a business plan in general are taught in Brazil as if the plans were great pedagogical objectives, leaving in the background the mastery of techniques, tools, and updated planning models, and as well as the comprehension of entrepreneurship, planning, calculated risk, relationships between environment and identification / exploitation of opportunities, among other related aspects. Specifically, the types of planning (situational, strategic, tactical, operational) are not well explored, just as there is little development of the competency to monitor and track indicators, adjusting them to changes in the competitive environment and the internal resources of the organizations. As stated in the theoretical part of this article, the approaches of planning as a cause and as a consequence are quite appropriate for strengthening the performance of entrepreneurs in any environment, who can handle them appropriately according to changes in the competitive environment in which they operate (Sarasvathy, 2001; Shane \& Venkataraman, 2000).

\subsubsection{Perception of control (risk assessment)}

The less propensity for calculated risk (CR) category was manifested in eight cases and the greater propensity for calculated risk (PR) category, in seven cases. Examples of less propensity for calculated risk: "let's go for it, if it works out, great, if not, then we'll see what we do next" (case 1); "I thought it would be a good thing, but I didn't analyze risks systematically, I didn't analyze competitors, I didn't do market research" (case 3); "I am willing to take that risk to try to do what I believe" (case 15). Examples of greater propensity for calculated risk: "I never asked for money at a bank, I always had working capital to pay the bills" (case 4); "I had a spreadsheet of how much money I would need, how much time I would need to see a return, and had a plan B in case things went wrong" (case 5).

There was relative balance in the manifestations of the two categories. It is assumed that the contact with the junior enterprise and the formation of networks of relationships, inside and outside the academic environment, provide entrepreneurs with a greater perception of viability of the business, a result of assessing the pros and cons and a clearerunderstanding of the legal issues (Ferreira \& Freitas, 2013, Malach \& Malach, 2019), but they also offer information and knowledge about the market, which may leave them afraid to take chances. Although Stewart and Roth (2001) state that entrepreneurs risk more than nonentrepreneurs, and the GEM (2015) states that there is a general profile of less propensity for calculated risk among Brazilian entrepreneurs, the result of this study relativizes this profile, signaling a moderate propensity for calculated risk. Future studies can deepen these findings, analyzing the risk assessment among junior enterprise alumni and entrepreneurs who have not gone through this experience.

\subsubsection{Entrepreneurial competencies}

The three categories provided for in the category system were manifested in the cases studied, although some subcategories have emerged. Competency for organization (OR) was manifested in five cases, for instance, cases 2, 3, and 11: "I have abilities for leadership, defining tasks, organization"; "I am very controlling"; "I am very realistic, I have my feet on the ground. But I manage to do financial management reasonably well". The competency for opportunity (OP) category was also manifested in five cases, for example: "I can visualize opportunities and create opportunities" (case 9); "We perceived that the market is greatly expanding" (case 7); "I discovered an opportunity in the market" (case 5). The competency for relationships (RL) category was manifested in three cases, for example, in case 4: "I relate easily to people".

There was variety in the reports, including some who were unable to say what competencies they possessed, such as the entrepreneur in the case 12: "I can't say, I never studied entrepreneurship". Some competencies appeared simultaneously in the same case, for example: "knowing how to deal with people, planning, organizing" (case 1). The competencies for persistence and risk taking emerged in the reports, although they had not been initially foreseen, for example: "knowing how to take calculated risks" (case 1); "persistence, faith, spiritual belief, capacity to believe in what you are doing" (case 7). These results contribute to the seminal and recent discussions about the different typologies of entrepreneurial competencies (Campos, 2011; Man, 2000; Michelmore \& Rowley, 2010; Tittel \& Terzidis, 2020). The most widespread are those of Man (2001), who describes six types of competencies (opportunity, strategic, conceptual, organizational / administrative, commitment, and relationship). Other typologies of competencies do not differentiate skills, abilities, and characteristics (Michelmore \& Rowley, 2010), showing a panorama still marked by incompleteness and theoretical immaturity (Tittel \& Terzidis, 2020). Campos' research (2015) showed that entrepreneurial competencies of junior alumni are not necessarily framed in previously defined typologies (e.g., strategic analysis, business expertise, innovation). 


\subsubsection{Entrepreneurial competencies and sex}

The categories referring to males (attributes of objectivity - $A B$ ) and to females (analytical attribute - AA) were observed in all cases in a similar way, that is, most entrepreneurs believe there are characteristics linked to one's sex, but besides being seen in a very positive way, they do not interfere in the success of the business, for example: "I honestly think that today both men and women have competencies, although I think that there is a distinction of characteristics peculiar to each sex; men are more careless, women are more organized" (case 9). What was observed, however, was the belief, especially by women, that they suffer prejudices, as shown by the female entrepreneur's words in case 11: "When I go to negotiate a deal with men, at first sight they don't give me credit, because I'm a woman, and second, my physiognomy is that of a person younger than I am. I've been through situations where I was asked if I was of adult age, if I was registered with the regional professional council, if I could sign the documents, hahaha, whether I didn't have a colleague who could take responsibility for the job. Regarding the competencies to run the business, I think there is no difference". When asked if there would be gender-specific differences in the competencies of entrepreneurs, there was a participant who highlighted some of them, revealing distinctions in the socialization process of men and women, such as case 6: "women have a higher capacity for daily execution than do men, they are somehow more focused and can perform better. Perhaps the man has in his favor more calmness for dealing with problems, to have the guts to deal with certain things".

The interviews draw out a picture still common in society (Gupta et al., 2008). There is still a predominance of males in entrepreneurship, although the number of females has increased in recent years, as shown by the GEM (2015), which is quite positive. However, entrepreneurial competencies do not seem to differ between the sexes, despite the research by Shinnar, Giacomin and Janssen (2012) revealing that women in the U.S. reported having less entrepreneurial competencies than men. As Sweida and Reichard (2013) well consider, people think and act differently when they become aware of a stereotype. Entrepreneurial women seem to be aware of the existence of the stereotype that men possess a better profile for entrepreneurship than they do, and this can negatively impact how women think and perform tasks related to entrepreneurship. Future research deserves to better investigate gender differences with regard to entrepreneurial characteristics, as suggested by SánchezEscobedo et al. (2016).

The summary of each case, presented in Table 4 , provides key information on the perception of each entrepreneur on the topics worked on in the interviews.

Table 4

Case summary

To work in the area of his training ${ }^{1 ;}$ Parent's death and state of health"; Didn't know what to dowith his life ${ }^{3}$; Enjoying being ahead of things ${ }^{4}$; Financial opportunity, quality of life and professional fulfillment ${ }^{5}$; Husband's Motivations employment terminated and difficulty finding work ${ }^{6}$; Opportunity discovered after making a business planat the end of undergraduate studies ${ }^{7}$; Express herself creatively and find meaning in work ${ }^{8}$

${ }^{1}$ Cases 1 and $9 ;{ }^{2}$ Cases 2, 8 and $10 ;{ }^{3}$ Cases 2 e $4 ;{ }^{4}$ Cases 3 e $11 ;{ }^{5}$ Cases 5 and $12 ;{ }^{6}$ Cases 6 and $14 ;{ }^{7}$ Case 7; ${ }^{8}$ Cases 13 and 15.

Career permeated by many challenges ${ }^{1}$; Quality of life and relationships that the career offers ${ }^{2}$; Freedom to put your ideas into practice ${ }^{3}$, Career with high level of stress, uncertainty and requiring good time management ${ }^{4}$; Attitudes Alternative career he always wanted and thinks that is not for everyone ${ }^{5}$; Career that requires a lot of resistance to the ups and downs ${ }^{6}$

${ }^{1}$ Cases 1, 5, 8 and $11 ;{ }^{2}$ Cases 2, 3 and $10 ;{ }^{3}$ Cases 4, 6 and $7 ;{ }^{4}$ Cases 9 and $12 ;{ }^{5}$ Cases 13 and $14 ;{ }^{6}$ Case 15.

\section{Perception of Usually don't take chances without analyzing the scenario ${ }^{1}$; Did not assess risks ${ }^{2}$; Assessed risks formally and}

Control informally ${ }^{3}$; From the contact with JE and her father's company, believes in the viability of her business ${ }^{4}$. ${ }^{1}$ Cases 1 and $2 ;{ }^{2}$ Cases $3,4,8,12$ and $15 ;{ }^{3}$ Cases 5, 6, 7, 9 and $13 ;{ }^{4}$ Cases 10,11 and 14

\section{No business plandone ${ }^{1}$; Done in the day to day of thebusiness ${ }^{2}$; Assessed the resources needed toinvest ${ }^{3}$; Did a} Planning business plan ${ }^{4}$.

${ }^{1}$ Cases $1,3,8,12,13$ and $14 ;{ }^{2}$ Cases $2,4,5,10$ and $15 ;{ }^{3}$ Cases 6 and $9 ;{ }^{4}$ Cases 7 and 11

\section{Competencies Entrepreneurial}

Entrepreneurial Competencies and sex

\begin{tabular}{l}
$\begin{array}{l}\text { Subjective } \\
\text { Norms }\end{array}$ \\
\hline $\begin{array}{l}\text { Entrepreneurial } \\
\text { Education }\end{array}$
\end{tabular}

Leadership, organization, relationships and risktaking ${ }_{1}$; Persistence and control ${ }^{2}$; planning, creativity and proactiveness 3 ; Likes to solve problems ${ }^{4}$ Does not know ${ }^{5}$

${ }^{1}$ Cases $1,2,4,11$ and $14,{ }^{2}$ Cases 3,7 and $15 ;{ }^{3}$ Cases $5,6,8,9,13$ and $15 ;{ }^{4}$ Case $10 ;{ }^{5}$ Case 12

Gender differences do not influence business success ${ }^{1}$; There is no distinction, although men have more advantage in society2; They all have masculine and feminine energies, although affirms that women are more subtle, disciplined, empathic, detailed, flexible, emotional,creative and have a better capacity for execution, and that men aremore pragmatic, practical and perhaps calmer in dealing with problems ${ }^{3}$; Sees different characteristics of each one, but all are competent ${ }^{4}$

Cases 1, 7, 10,11 and 12; Cases 4, 5 and 14; Cases 2, 3, 6, 8, 13 and 15. Case 9.

Socio-emotional and financial support from parents and family ${ }^{1}$; Received support from fellowpartners and friends ${ }^{2}$.

${ }^{1}$ Cases $1,2,4,5,6,8,9,10,11,12$ and $13 ;{ }^{2}$ Cases $3,7,8,12,14$ and 15

Internships and participation in $\mathrm{JE}^{1}$; Attended only one entrepreneurship course ${ }^{2}$; The two courses he had during his undergraduate studies influenced his decision less than theexternal environment did ${ }^{3}$; The university and the faculty have not yet awakened to entrepreneurship, using repetitive methods ${ }^{4}$

${ }^{1}$ Cases $1,2,4,6,7,8,10,11,12,13,14$ and $15 ;{ }^{2}$ Case $3 ;{ }^{3}$ Case $5 ;{ }^{4}$ Case 9. 


\subsection{Proposed simplified comprehensive model of trajectories of junior enterprise alumni based on antecedents of entrepreneurship}

The simplified comprehensive model of relationships between variables investigated based on the trajectories of the 15 cases analyzed is shown in Figure 1. The model consists of three levels with dimensions and subdimensions, which are inter-influential.

At level 1, individual, the multiple motivations precede engagement in the university entrepreneurial experience, which, in turn, leads to complex attitudes and flexible behaviors. These attitudes and behaviors lead to relativization of planning as necessary or no to business, depending of context, and leads also to calculate risks. The experiences are important situations that the junior enterprises alumni reveal.

At level 2, called the university context, there are the dimensions "Entrepreneurial Education and Training", "Institutional Environment", "Social Environment", "Junior Enterprises", "Network of Colleagues", "informal groups" and "teaching of entrepreneurship". At level 3 is the family and social context, composed of the Social, financial and Material Support dimension, articulating the subjective norms that influence the actions of the entrepreneurs.

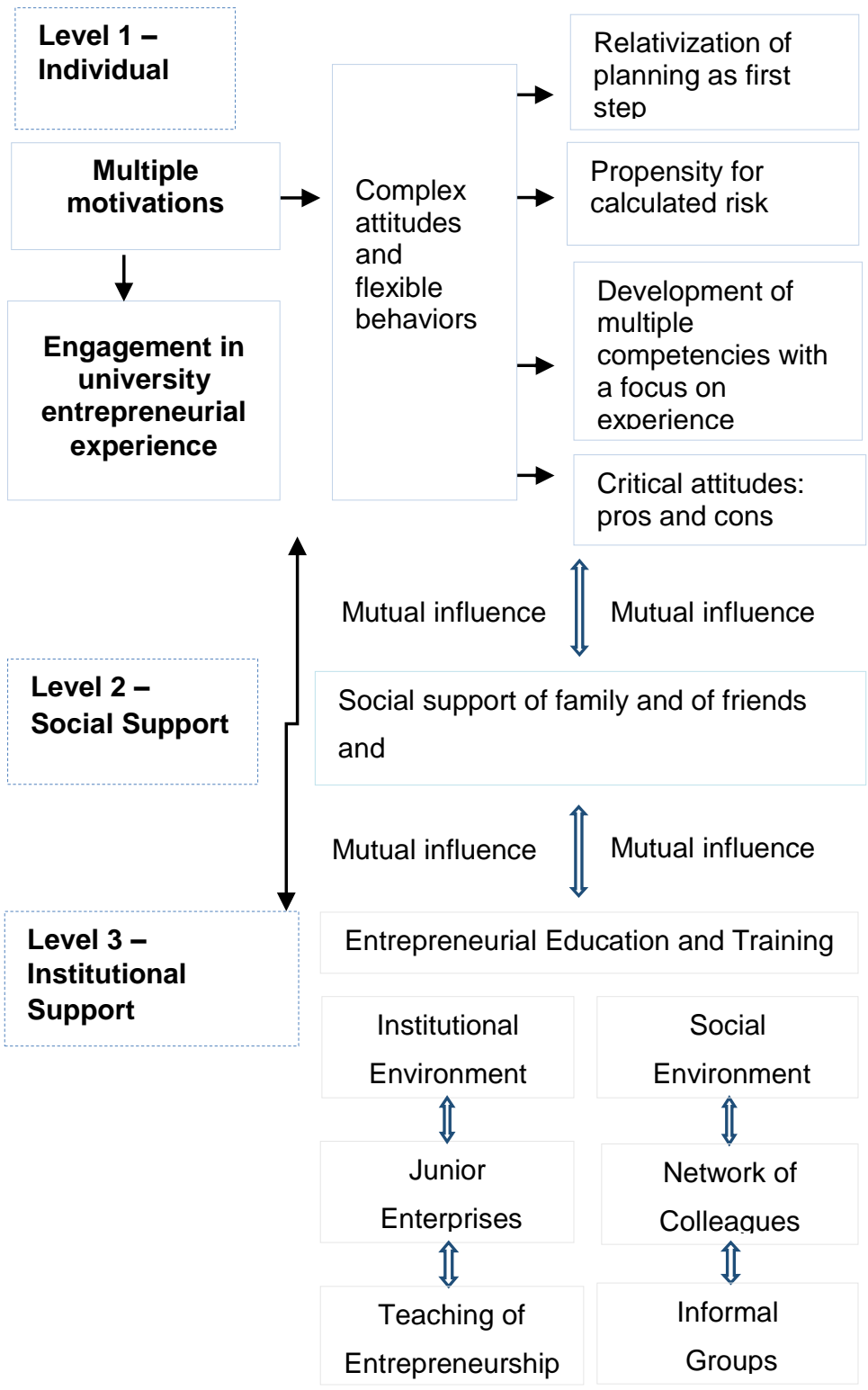

Figure 1. Comprehensive theoretical model of trajectories of junior enterprise alumni based on antecedents of entrepreneurship Source: Developed by the authors.

The model indicates that the motivations for entrepreneurship are of a diverse nature, from those more linked to the search for personal achievement to those related to identifying opportunities and to the circumstances and necessities of life, such as the death of a parent. These motivations can make young people more aware of the contextual variables that offer opportunities to engage in learning activities that involve entrepreneurship, such as those that take place in the university environment. This ability to identify and take advantage of such opportunities, even if they are scarce, in view of the criticisms made of the university environment, also seems to be positively associated with a family environment that values autonomy, independence, and offers social support for the risks of 
venturing out in entrepreneurial activities, and even material support.

When motivations are transformed into action, with young people engaging in an entrepreneurial experience in the university education environment, some changes occur. Learning in a safe training environment frees young people to think more flexibly, being able to better assess the pros and cons, in addition to critically reflecting on the importance of prior planning and decision making, which always involves risk. The experience also helps to relativize the losses and failures, exercising the attitude of persistence and opening doors for creativity. In other words, experience opens doors for daring and being able to make mistakes.

The development of technical competencies for entrepreneurship is a consequence of the quality of experience that each young person can extract from their practice. In this case, there are individual differences. In summary, the proposed comprehensive model is consistent with the theory of planned behavior (Ajzen, 1991) and advances by offering a view of how individual and contextual variables can contribute to transforming intention into entrepreneurial action. Although the model graphically represents the relationships between variables inferred from the trajectories of only 15 cases of young entrepreneurs who are junior enterprises alumni, it generates inputs about the adjustments between individual and environment involved, as the cases of entrepreneurial education and social and material / financial support, in building an entrepreneurial career.

\section{FINAL CONSIDERATIONS}

Five conclusions derive from this study. The first is that although the achievement motive is prominent, the results point to multiple motivations that are manifested simultaneously, such as opportunity and necessity, and the search for quality of life and running the business due to the death of parents. The second, the results show a scenario in which the entrepreneurial career is positively assessed, even recognizing its complex features, which involve everything from the bureaucratic-legal aspects to the assumption of responsibilities, thus relativizing the tendency toward propensity for risk, which in this study was moderate. Future studies could compare the risk propensity between graduates and non-graduates of junior companies, in order to analyze the influence of $\mathrm{EJ}$ in the entrepreneurial career.

The third is that despite a variety of motivations, the experience in junior enterprises helps in developing more flexible attitudes, thoughts, and behaviors that allow young people to face the vicissitudes of the act of entrepreneurship. Other studies could investigate whether entrepreneurship education, moderated by participation in EJ, influences students' motivations and attitudes. In relation to genre, although they recognize that there are differences between men and women entrepreneurs, signaling the incorporation of social stereotypes, no differentiated trajectories were identified for men and women entrepreneurs in this study. What can be deepened, from the results, is the question of prejudice still existing with women entrepreneurs, that is, what types of prejudices do women entrepreneurs suffer?

The fourth conclusion indicates that university education is critically assessed for offering few and limited opportunities for entrepreneurial training. However, any opportunity offered during the academic training period becomes attractive to young people who demonstrate entrepreneurial motivations, especially when the family is seen as a source of emotional support for this choice. Hence the importance of the university being better prepared to provide an entrepreneurial environment more attractive to the student, for example, what the support the JEs receive from your Institution of Teaching?

The fifth conclusion suggests that although the family may actually offer entrepreneurial models, its main role is in their social support, encouraging young people to take risks in new paths. The university in turn contributes indirectly to the development of competencies by creating spaces for the entrepreneurial experience to be practiced. The development of entrepreneurial competencies would be a consequence of the quality of this experience, which includes the network of social relationships constructed, capable of staying active beyond the limits of the university. The university seems to contribute little in terms of formal learning by offering courses involving entrepreneurship but it's contribution may be increased.

Some limitations of the study are pointed out. Two methodological limitations appear more visibly. The first stems from the recognition that qualitative interviews are based on the subjectivity of the actors, imposing limits on the generalization of results. In other words, qualitative interviews allow us to approach and better understand the complexity of dynamic phenomena in the light of the subjective perception and affective experiences of social actors, but they carry many subjective biases. The second limitation is related to the previous limitation and stems from the sample composition. Bearing in mind that the participants in this study were selected in a non-random manner, it cannot be said that the trajectories of these young entrepreneurs who are junior enterprises alumni represent this social category. As for the interview script, parental influence in relation to gender was not addressed, as found in the study by Molina (2020), which opens up a promising line of future research to understand the role of men and women in their children's entrepreneurial careers. In this study, we were able to analyze the distinction of gender when it comes to the perception of entrepreneurial skills, but future studies can advance this theme by also investigating the different reasons for entrepreneurship by gender. Another promising aspect to be explored in future studies is the role of family succession in entrepreneurial intention, since it may suggest less personal motivation and more moral obligation, which is a characteristic of the subjective norm. Entrepreneurial skills (persistence and risk-taking) 
also suggest that they are important predictors of entrepreneurship, which also opens up possibilities to deepen their relations in future studies (Tittel \& Terzidis, 2020).

From a practical point of view, the results and the proposed simplified comprehensive model may come to support entrepreneurial training actions in the university context, especially those aimed at enhancing the experience in junior enterprises. Despite being a movement triggered by the initiative of university students, university management may come to offer greater material and human resources support that enhance such learning activities and the development of multiple competencies.

\section{REFERENCES}

Ajzen, I. (1991). The Theory of Planned Behavior. Organizational Behavior and Human Decision Processes, 50(2), 179-211. https://doi.org/10.1016/0749-5978(91)90020-T

Barbosa, R. A. P., Silva, E. A., Gonçalves, F. H. L., \& Morais, F. R. (2020). O impacto da educação empreendedora na intenção de empreender: análise dos traços de personalidade. Rev. Empreendedorismo Gest. Pequenas Empres. $9(1)$ https://doi.org/10.14211/regepe.v9i1.1589

Bardin, L. (2009). Análise de Conteúdo. São Paulo: Martins Fontes.

Baron, R. A., \& Ensley, M. D. (2006). Opportunity recognition as the detection of meaningful patterns: Evidence from comparisons of novice and experienced entrepreneurs. Management Science, 52(9), 1331-1344. https://doi.org/10.1287/mnsc. 1060.0538

Barba-Sánchez, V., \& Atienza-Sahuquillo, C. (2012) Entrepreneurial behavior: Impact of motivation factors on decision to create a new venture. Investigaciones Europeas de Dirección y Economía de la Empresa, 18(2), 132-138. https://doi.org/10.1016/S1135-2523(12)70003-5

Botha, M., \& Robertson, C. L. (2014). Potential entrepreneurs' assessment of opportunities through the rendering of a business plan. South Africa Journal of Economy and Management Sciences, 17(3), 249-265. https://www.scielo.org.za/pdf/sajems/v17n3/02.pdf

Brasil Júnior (2014). Relatório Nacional Censo e Identidade 2014. https://uploads.brasiljunior.org.br/uploads/cms/institutional /file/file/2/Censo Identidade 2014 - VF.pdf

Campos, E. B. D. (2015). Competências empreendedoras: uma avaliação no contexto de empresas juniores brasileiras (Tese de Doutorado). Universidade de Brasília, Brasília, DF, Brasil.

Chandler, G. N., Detienne, D. R., Mckelvie, A., \&Mumford, T. V. (2011) Causation and effectuation processes: a validation study. Journal of Business Venturing, 26(1), 375-390. https://doi.org/10.1016/j.jbusvent.2009.10.006

Cooley, L. (1990). Entrepreneurship training and the strengthening of entrepreneurial performance. Final Report. Washington: USAID.

Corrêa, V. S., \& Vale, G. M. V. (2014). Redes sociais, perfil empreendedor e trajetórias $R$. Adm., 49(1), 77-88. https://doi.org/10.5700/rausp1132

Cortez, P. A., Veiga, H. M. S., \& Salvador, A. P. (2019). Impacto de personalidade e empresas juniores para estimular potenciais empreendedores. Arquivos Brasileiros de Psicologia, 71(2), 179-192. https://doi.org/10.36482/18095267.ARBP2019v71i2p.179-192
Creswell, J. W. (2007). Projeto de pesquisa: Métodos qualitativo, quantitativo e misto. Porto Alegre: Artmed.

Dawson, C., \& Henley, A. (2015) Gender, Risk, and Venture Creation Intentions. Journal of Small Business Management, 53(2), 501-515. http://ftp.iza.org/dp6947.pdf

Delaney, P. G., Harrington, K., \& Toker, E. (2019) Undergraduate student-run business development services firms: A new educational opportunity and growth alternative for small and medium enterprises. Entrepreneurship Education and Pedagogy, 2(2),

https://doi.org/10.1177/2515127418816289

D'hont, L., Doern, R., \& Delgado García, J. B. (2016). The role of friendship in the formation and development of entrepreneurial teams and ventures. Journal of Small Business and Enterprise Development, 23(2), 528561. https://doi.org/10.1108/JSBED-02-2015-0027

Engle, R. L., Dimitriadi, N., Gavidia, J. V., Schlaegel, C., Delanoe, S., Alvarado, I., He, X., Baume, S., \& Wolff, B. (2010). Entrepreneurial intent: A twelve-country evaluation of Ajzen's model of planned behavior. International Journal of Entrepreneurial Behavior \& Research, 16(1), 35-57. https://doi.org/10.1108/13552551011020063

Faia, V. S., Rosa, M. A. G., \& Machado, H. P. V. (2014). Alerta empreendedor e as abordagens causation e effectuation sobre empreendedorismo. RAC, 18(2), 196-216. https://doi.org/10.1590/S1415-65552014000200006

Fellnhofer, K. (2018). Narratives boost entrepreneurial attitudes: Making an entrepreneurial career attractive? Eur. J. Educ., 53(2), 218-237. https://doi.org/10.1111/ejed.12274

Ferreira, E. R. A., \& Freitas, A. A. F. (2013) Propensão empreendedora entre estudantes participantes de empresas juniores. REGEPE, 2(3), 3-32. https://doi.org/10.14211/regepe.v2i3.69

Ferreira, A. S. M., Loiola, E., \& Gondim, S. M. G. (2020). Produção científica em empreendorismo no Brasil: Uma revisão de literatura de 2004 a 2020. Revista Gestão e Planejamento, 21, 371-393. $\quad$ https://doi.org/10.21714/21788030gep.v.21.5618

Ferreira, A. S. M., Loiola, E., \& Gondim, S. M. G. (2017). Preditores individuais e contextuais da intenção empreendedora entre universitários: revisão de literatura. Cad. EBAPE.BR, 15(2), 292-308. https://doi.org/10.1590/1679-395159595

Fina, A. (2015). Narrative and identities. In A. Fina \& A. Georgakopoulou (Eds.), The Handbook of Narrative Analysis (pp. 351-368). Oxford, England: John Wiley \& Sons, Inc.

Garcia, R., Araújo, V., Mascarini, S., Silva, A. O., \& Ascúa, R. (2012). Empreendedorismo acadêmico no Brasil: uma avaliação à criação de empresas por alunos universitários. REGEPE, 1(3), 3663. https://doi.org/10.14211/regepe.v1i3.39

Global Entrepreneurship Monitor - GEM (2015). Empreendedorismo no Brasil (Relatório Executivo). Curitiba: Instituto Brasileiro de Qualidade e Produtividade.

Gondim, S. M. G., \& Bendassoli, P. F. (2014) Uma crítica da utilização da análise de conteúdo qualitativa em psicologia. Psicologia em Estudo, 19(2), 191-199. https://doi.org/10.1590/1413-737220530002

Giménez, E. L., \& Novo, J. A. (2020). A Theory of Succession in family firms. Journal of Family and Economic Issues, 41(1), 96-120. https://doi.org/10.1007/s10834-019-09646-y

Gupta, V. K., Turban, D. B., \& Bhawe, N. M. (2008). The effect of gender stereotype activation on entrepreneurial Intentions. Journal of Applied Psychology, 93(5), 1053-1061. https://doi.org/ 10.1037/0021-9010.93.5.1053

Hammersley, M. (2010). Reproducing or constructing? Some questions about transcription in social research. Qualitative 
Ferreira, Loiola \& Gondim - Antecedents of entrepreneurship in the career trajectories of junior enterprises alumni

Research, 10(5),

https://doi.org/10.1177/1468794110375230

Kacperczyk, A. J. (2013). Social influence and entrepreneurship: The effect of university peers on entrepreneurial entry. Organization Science, 24(3), 664-683. https://doi.org/10.2139/ssrn.1961386

Komulainen, K., Siivonen, P., Kasanen, K., \& Raty, H. (2020). How to give a killer pitch? Performances of entrepreneurial narratives as identity models in higher education. Entrepreneurship Education and Pedagogy, 3(3), 214-235. https://doi.org/10.1177/2515127420908039

Kautonen, T., Van Gelderen, M., \& Fink, M. (2015) Robustness of the theory of planned behavior in predicting entrepreneurial intentions and actions. ETP, 39(3), 655674. https://doi.org/10.1111/etap.12056

Krueger, N., \& Carsud, A. (1993). Entrepreneurship intentions: applying the theory of planned behaviour. Entrepreneurship \& Regional Development, 5(4), 315-330. https://doi.org/ $\underline{10.1080 / 08985629300000020}$

Liñán, F., Urbano, D., \& Guerrero, M. (2011). Regional variations in entrepreneurial cognitions: Start-up intentions of university students in Spain. Entrepreneurship \& Regional Development, 23(3-4), https://doi.org/10.1080/08985620903233929

187-215.

Liñán, F., \& Fayolle, A. (2015). Asystematic literature review on entrepreneurial intentions: citation, thematic analyses, and research agenda. Int. Entrep. Manag. J., 11(4), 907-933. https://doi.org/10.1007/s11365-015-0356-5

Liñán, F., Ceresia, F., \& Bernal, A. (2018). Who intends to enroll in entrepreneurship education? Entrepreneurial selfidentity as a precursor. Entrepreneurship Education and Pedagogy, 1(3), 222-242. https://doi.org/10.1177/2515127418780491

Lima, E., Lopes, R. A., Nassif, V. M. J., \& Silva. D. (2015). Ser seu próprio patrão? Aperfeiçoando-se a educação superior em empreendedorismo. RAC, 19(4), 419-439. https://doi.org/10.1590/1982-7849rac20151296

Malach, S. E., \& Malach, R. L. (2019). Regulatory and risk management issues arising in the contextof experiential entrepreneurship education. Entrepreneurship Education and Pedagogy, 2(1) 82-95. https://doi.org/10.1177/2515127418818052

Man, T. W. Y. (2001). Entrepreneurial competencies and the performance of small and medium enterprises in the Hong Kong services sector (PhD dissertation). Polytechnic University, Hong Kong.

McClelland, D.C. (1965). Toward a theory of motive acquisition. American Psychologist, 20(5), 321-333. https://doi.org/ $10.1037 / \mathrm{h} 0022225$

Mitchelmore, S., \& Rowley, J. (2010). Entrepreneurial competencies: a literature review and development agenda. International Journal of Entrepreneurial Behavior \& Research, 16(2), 92-111. https://doi.org/10.1108/13552551011026995

Molina, J. A. (2020). Family and entrepreneurship: New empirical and theoretical results. J. Fam. Econ. Iss., 41, 1-3. https://doi.org/10.1007/s10834-020-09667-y

Moraes, G. H. S. M., lizuka, E. S., \& Pedro, M. (2018). Effects of entrepreneurial characteristics and university environment on entrepreneurial intention. Revista de Administração Contemporânea, 22(2), 226248. https://doi.org/10.1590/1982-7849rac2018170133

Mushtaq, H. A., Hunjra, A. I., Niazi, S. K., Rehman, K., \& Azam, R. I. (2011). Planned behavior entrepreneurship and intention to create a new venture among young graduates. Management \& Marketing Challenge for the Knowledge Society, 6(3), 437456. https://doi.org/10.2139/ssrn.1944685
Ngan, N. T., Khoi, B. H. (2020). Using AIC in model choice about entrepreneurial attitude orientation. International Journal of

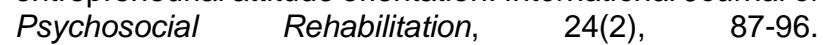
https://doi.org/10.37200/IJPR/V24I2/PR200313

Paiva, L. E. B., Sousa, E. S., Lima, T. C. B., \& Dilva, D. (2020). Comportamento planejado e crenças religiosas como antecedentes da intenção empreendedora: um estudo com universitários. RAM. Revista de Administração Mackenzie, 21(2). https://doi.org/10.1590/16786971/eramg200022

Palassi, M. P., Martinelli, R. G. O., \& Paula, A. P. P. (2020). Between entrepreneurial discourse and political awareness: an exploratory study of the Junior Enterprise Movement at a public university in Southeast Brazil. Cadernos EBAPE.BR, 18(1), 3-12. https://doi.org/10.1590/1679-395172642x

Parreira, P., Pereira, F. C., \& Brito, N. V. (2011). Empreendedorismo e Motivações Empresariais no Ensino Superior. Lisboa: Edições Sílabo.

Reeves, P. M., Sarah, E., Zappe, S. E., \& Follme, D. J. (2019). A comparison of the types of problems encountered by entrepreneurial students and successful professional entrepreneurs. Entrepreneurship Education and $\begin{array}{lll}\text { Pedagogy, } & \text { 2(3), 214-244. }\end{array}$ https://doi.org/10.1177/2515127419829396

Salusse, M. A. Y., \& Andreassi, T. (2016). O ensino de empreendedorismo com fundamento na Teoria $\begin{array}{lll}\text { Effectuation. } & \text { 20(3), } & \text { 305-27. }\end{array}$ https://doi.org/10.1590/1982-7849rac2016150025

Sánchez-Escobedo, M. C., Fernández-Portillo, A., Díaz-Casero, J. C., \& Hernández-Mogollón, R. (2016). Research in entrepreneurship using GEM data. Approach to the state of affairs in gender studies. European Journal of Management and Business Economics, 25, 150-160. https://doi.org/ 10.1016/i.redeen.2016.09.002

Sarasvathy, S. D. (2001). Causation and effectuation: Toward a theoretical shift from economic inevitability to entrepreneurial contingency. Academy of Management Review, 26(2), 243-263. https://doi.org/10.5465/AMR.2001.4378020

Savoie, M. L., Bendickson, J. S., \& Edwards, C. J. (2018) Embedding MBA students in local incubators and accelerators. Entrepreneurship Education and Pedagogy, 1(3), 243-257. https://doi.org/10.1177/2515127418779974

Sesen, H. (2013). Personality or environment? A comprehensive study on the entrepreneurial intentions of university students. Education + Training, 55(7), 624-640. https://doi.org/10.1108/ET-05-2012-0059

Shane, S., \&Venkataraman, S. (2000). The Promise of Entrepreneurship as a Field of Research. In A. Cuervo, D. Ribeiro \& S. Roing (Eds). Entrepreneurship: Concepts, Theory and Perspective (pp. 171-184). New York: Springer.

Shinnar, R. S., Giacomin, O., \& Janssen, F. (2012). Entrepreneurial perceptions and intentions: the role of gender and culture. ETP, 36(3), 465-493. https://doi.org/10.1111/j.1540-6520.2012.00509.x

Schmitt, C., Pierre-André, J. (2020). Causation, effectuation, improvisation et agir entrepreneurial. Pour une approche renouvelée et intégrative de l'entrepreneuriat. Proyéctica, 1(25), 131-153. https://doi.org/10.3917/proj.025.0131

Souza, C. F. (2005). Competência empreendedora dos gestores de negócios de moda. Enanpad 2005, Brasília, Brasil, 29. http://www.anpad.org.br/admin/pdf/enanpad2005-gpra2782.pdf

Stewart, W. H., Jr., \& Roth, P. L. (2001). Risk propensity differences between entrepreneurs and managers: A meta-analytic review. Journal of Applied Psychology, 

86(1), $\underline{9010.86 .1 .145}$

Støren, L. A. Entrepreneurship in higher education. Education + Training, 56(8/9), 795-813. https://doi.org/10.1108/ET-06$\underline{2014-0070}$

Sweida, G. L., \& Reichard, R. J. (2013).Gender stereotyping effects on entrepreneurial self-efficacy and high-growth entrepreneurial intention. Journal of Small Business and Enterprise Development, 20(2), 296-313. https://doi.org/10.1108/14626001311326743

Tittel, A., Terzidis, O. (2020). Entrepreneurial competences revised: developing a consolidated and categorized list of entrepreneurial competences. Entrep.Educ., 3, 1-35. https://doi.org/10.1007/s41959-019-00021-4

Vale, G. M. V., Corrêa, V. S., \& Reis, R. F. (2014). Motivações para o empreendedorismo: Necessidade versus oportunidade? $\quad R A C, \quad 18(3), \quad 311-327$. https://doi.org/10.1590/1982-7849rac20141612

Vale, G. M. V., Serafim, A. C. F., \& Teodósio, A. S. S. (2011). Gênero, imersão e empreendedorismo: sexofrágil, laços fortes? Rev. Adm. Contemp., 15(4), 631-649. http://doi.org/10.1590/S1415-65552011000400005

Varamäki, E., Joensuu, S., Tornikoski, E., \& Viljamaa, A. (2015). The development of entrepreneurial potential among higher education students. Journal of Small Business and Enterprise Development, 22(3), 563-589. https://doi.org/10.1108/JSBED-02-2012-0027

Wengraf, T. (2001). Preparing moderately - or heavily - structured interviews. In T. Wengraf. Qualitative Research Interviewing (pp. 152-182). SAGE Publications, Ltd. https://www.doi.org/10.4135/9781849209717

Zampier, M. A., \& Takahashi, A. R. W. (2011). Competências empreendedoras e processos de aprendizagem empreendedora: modelo conceitual de pesquisa. Cadernos Ebape.br, 9(6), 564-585. https://doi.org/10.1590/S1679-39512011000600007

Zawadzki, M., Jałocha, B., Mazurkiewicz, G., Pluszynska, A., \& Prawelska-Skrzypek, G. (2020). Unrooting management education and entrepreneurial self from neoliberal demands: An action research approach. Entrepreneurship Education and Pedagogy, 3(3) 265-290. https://doi.org/10.1177/2515127420912399 


\section{CONTEXTUS}

\section{REVISTA CONTEMPORÂNEA DE ECONOMIA E GESTÃO}

\section{CONTEXTUS}

CONTEMPORARY JOURNAL OF ECONOMICS AND

MANAGEMENT.

\section{ISSN 1678-2089}

ISSNe 2178-9258

1. Economics, Administration and Accounting - Journal

2. Federal University of Ceara. Faculty of Economics,

Administration, Actuaries and Accounting

\section{FACULTY OF ECONOMICS, ADMINISTRATION, ACTUARIES} AND ACCOUNTING

University Av. - 2486, Benfica

60020-180, Fortaleza-CE

BOARD: Paulo Rogério Faustino Matos Danielle Augusto Peres

Website: www.periodicos.ufc.br/contextus

E-mail: revistacontextus@ufc.br

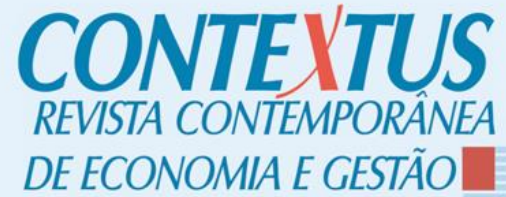

UNIVERSIDADE

FEDERAL

DO CEARÁ

FACULDADE

DE ECONOMIA,

ADMINISTRAÇÃO,

ATUÁRIA

E CONTABILIDADE

\section{Qlualis}

Contextus is classified in the Qualis - Capes system as a B1 journal, in the area of Public and Business Administration, Accounting and Tourism (2013-2016).

DORA

Contextus agrees and signs the San Francisco Declaration on Research Assessment (DORA).

$\triangle B E C$ Contextus is associated with the Brazilian BRASIL Association of Scientific Editors.

This work is licensed under a Creative Commons Attribution - NonCommercial 4.0 International license.
EDITOR-IN-CHIEF

Diego de Queiroz Machado (UFC)

\section{ASSISTANT EDITORS}

Alane Siqueira Rocha (UFC)

Márcia Zabdiele Moreira (UFC)

\section{ASSOCIATE EDITORS}

Adriana Rodrigues Silva (IPSantarém, Portugal)

Alessandra de Sá Mello da Costa (PUC-Rio)

Andrew Beheregarai Finger (UFAL)

Armindo dos Santos de Sousa Teodósio (PUC-MG)

Brunno Fernandes da Silva Gaião (UEPB)

Carlos Enrique Carrasco Gutierrez (UCB)

Dalton Chaves Vilela Júnior (UFAM)

Elionor Farah Jreige Weffort (FECAP)

Gabriel Moreira Campos (UFES)

Guilherme Jonas Costa da Silva (UFU)

Henrique César Muzzio de Paiva Barroso (UFPE)

Jorge de Souza Bispo (UFBA)

Keysa Manuela Cunha de Mascena (UNIFOR)

Manuel Anibal Silva Portugal Vasconcelos Ferreira (UNINOVE)

Marcos Cohen (PUC-Rio)

Marcos Ferreira Santos (La Sabana, Colombia)

Mariluce Paes-de-Souza (UNIR)

Minelle Enéas da Silva (La Rochelle, France)

Pedro Jácome de Moura Jr. (UFPB)

Rafael Fernandes de Mesquita (IFPI)

Rosimeire Pimentel (UFES)

Sonia Maria da Silva Gomes (UFBA)

Susana Jorge (UC, Portugal)

Thiago Henrique Moreira Goes (UFPR)

\section{EDITORIAL BOARD}

Ana Sílvia Rocha Ipiranga (UECE)

Conceição de Maria Pinheiro Barros (UFC)

Danielle Augusto Peres (UFC)

Diego de Queiroz Machado (UFC)

Editinete André da Rocha Garcia (UFC)

Emerson Luís Lemos Marinho (UFC)

Eveline Barbosa Silva Carvalho (UFC)

Fátima Regina Ney Matos (ISMT, Portugal)

Mario Henrique Ogasavara (ESPM)

Paulo Rogério Faustino Matos (UFC)

Rodrigo Bandeira-de-Mello (FGV-EAESP)

Vasco Almeida (ISMT, Portugal)

\section{SCIENTIFIC EDITORIAL BOARD}

Alexandre Reis Graeml (UTFPR)

Augusto Cezar de Aquino Cabral (UFC)

Denise Del Pra Netto Machado (FURB)

Ednilson Bernardes (Georgia Southern University, USA)

Ely Laureano Paiva (FGV-EAESP)

Eugenio Ávila Pedrozo (UFRGS)

Francisco José da Costa (UFPB)

Isak Kruglianskas (FEA-USP)

José Antônio Puppim de Oliveira (UCL)

José Carlos Barbieri (FGV-EAESP)

José Carlos Lázaro da Silva Filho (UFC)

José Célio de Andrade (UFBA)

Luciana Marques Vieira (UNISINOS)

Luciano Barin-Cruz (HEC Montréal, Canada)

Luis Carlos Di Serio (FGV-EAESP)

Marcelle Colares Oliveira (UFC)

Maria Ceci Araujo Misoczky (UFRGS)

Mônica Cavalcanti Sá Abreu (UFC)

Mozar José de Brito (UFL)

Renata Giovinazzo Spers (FEA-USP)

Sandra Maria dos Santos (UFC)

Walter Bataglia (MACKENZIE) 